\title{
Profile of bacterial pathogens contaminating hands of healthcare workers during daily routine care of patients at a tertiary hospital in northern Nigeria
}

\author{
${ }^{1}$ Ige, O. T., ${ }^{2}$ Jimoh, O., ${ }^{3}$ Ige, S. O., ${ }^{4}$ Ijei, I. P., ${ }^{5}$ Zubairu, H., and ${ }^{2}$ Olayinka, A. T. \\ ${ }^{1}$ Department of Medical Microbiology, Faculty of Basic Clinical Sciences, College of Medicine, \\ Kaduna State University, Kaduna, Nigeria \\ ${ }^{2}$ Department of Medical Microbiology, Faculty of Basic Clinical Sciences, College of Medicine, \\ Ahmadu Bello University Teaching Hospital, Shika, Kaduna, Nigeria \\ ${ }^{3}$ Department of Paediatrics, Yusuf Dantsofo Specialist Hospital, Kaduna, Nigeria \\ ${ }^{4}$ Department of Hematology, Faculty of Basic Clinical Sciences, College of Medicine, \\ Kaduna State University, Kaduna, Nigeria \\ ${ }^{5}$ Department of Family Medicine, Faculty of Clinical Sciences, College of Medicine, \\ Kaduna State University, Kaduna, Nigeria \\ Correspondence to: anjolaoluwanow@gmail.com; Mobile: 08133831264
}

\begin{abstract}
:
Background: Healthcare associated infections (HAIs) have been recognized as a critical challenge affecting the quality of healthcare services provided. A significant proportion of these infections result from cross-contamination of microorganisms which are often acquired and spread by direct contact with patients or contaminated adjacent environmental surfaces through the hands of healthcare workers (HCWs). The objectives of this study are to profile bacterial pathogens commonly found on the hands of health care workers while routinely attending to patients in the healthcare facility and to determine their antibiotic susceptibility pattern.

Methodology: The fingers of the dominant hand of $300 \mathrm{HCWs}$ at the Barau Dikko Teaching Hospital (BDTH), Kaduna, Nigeria, were imprinted on 5\% Sheep blood, MacConkey, and Mannitol salt agar plates and incubated at $37^{\circ} \mathrm{C}$ for 24 hours. Bacteria isolates were identified by Gram staining and conventional biochemical tests. The susceptibility of isolated bacteria to selected antibiotics was determined by the modified Kirby-Bauer disk diffusion method and interpreted using the 2012 guidelines of the Clinical and Laboratory Standards Institute.

Results: Bacteria were isolated from the hands of all $300 \mathrm{HCWs}$, with coagulase negative staphylococci (CONS) being the most frequent $(67.0 \%, 201 / 300)$. Other bacteria identified were Staphylococcus aureus $(23.7 \%$, MRSA of 3\%), Streptococcus pyogenes (2.7\%), and Enterobacteriaceae (6\%). The isolates were highly sensitive to ofloxacin $96.7 \%$ (290/300), augmentin 87.7\% (263/300) and ceftriaxone $87.3 \%(262 / 300)$.

Conclusion: This study demonstrates a high rate of contamination of hands of HCWs with potentially pathogenic bacteria, some of which were multidrug resistant. Concerted efforts should be made to implement programs dedicated to improve hand hygiene practices in the tertiary health care facility.
\end{abstract}

Keywords: Hand hygiene, bacterial, pathogen, healthcare workers, healthcare associated infection

Copyright 2021 AJCEM Open Access. This article is licensed and distributed under the terms of the Creative Commons Attrition 4.0 International License <a rel="license" href="http://creativecommons.org/licenses/by/4.0/", which permits unrestricted use, distribution and reproduction in any medium, provided credit is given to the original author(s) and the source. Editor-in-Chief: Prof. S. S. Taiwo

\section{Profil d'agents pathogènes bactériens contaminant les mains des travailleurs de la santé lors des soins quotidiens de routine aux patients d'un hôpital tertiaire dans le nord du Nigéria}

\author{
${ }^{1}$ Ige, O. T., ${ }^{2}$ Jimoh, O., ${ }^{3}$ Ige, S. O., ${ }^{4}$ Ijei, I. P., ${ }^{5}$ Zubairu, H., et ${ }^{2}$ Olayinka, A. T.
}




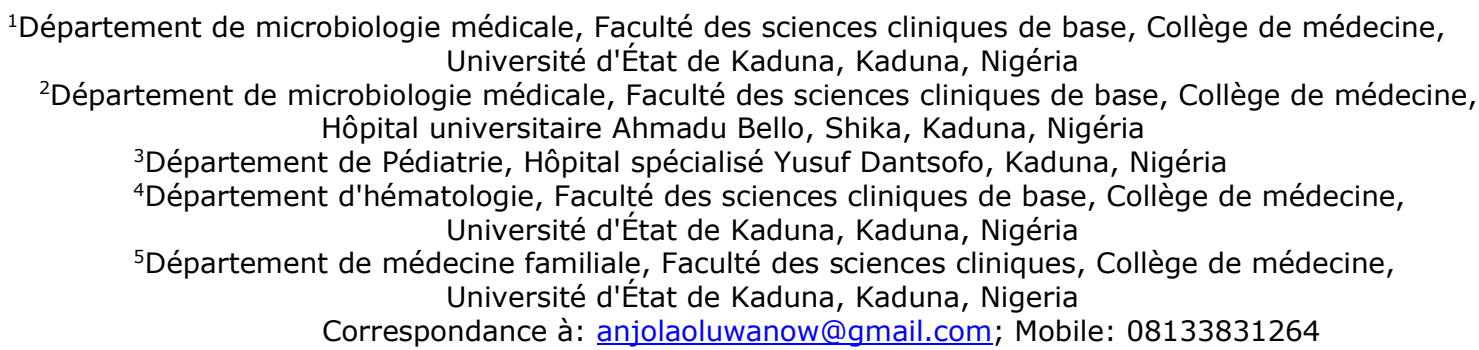

\begin{abstract}
Abstrait:
Contexte: Les infections associées aux soins de santé (IHA) ont été reconnues comme un défi critique affectant la qualité des services de santé fournis. Une proportion importante de ces infections résulte de la contamination croisée de micro-organismes qui sont souvent acquis et propagés par contact direct avec des patients ou des surfaces environnementales adjacentes contaminées par les mains des travailleurs de la santé (TS). Les objectifs de cette étude sont de dresser le profil des agents pathogènes bactériens que l'on trouve couramment dans les mains des travailleurs de la santé tout en s'occupant régulièrement des patients dans l'établissement de santé et de déterminer leur profil de sensibilité aux antibiotiques.

Méthodologie: Les doigts de la main dominante de 300 travailleurs de la santé au Barau Dikko Teaching Hospital (BDTH), Kaduna, Nigéria, ont été imprimés sur des plaques de gélose au sang de mouton à $5 \%$, MacConkey et Mannitol et incubés à $37^{\circ} \mathrm{C}$ pendant 24 heures. Les isolats de bactéries ont été identifiés par coloration de Gram et tests biochimiques conventionnels. La sensibilité des bactéries isolées aux antibiotiques sélectionnés a été déterminée par la méthode de diffusion sur disque modifiée de Kirby-Bauer et interprétée en utilisant les lignes directrices de 2012 du Clinical and Laboratory Standards Institute.

Résultats: les bactéries ont été isolées des mains des 300 TS, les staphylocoques à coagulase négative (CONS) étant les plus fréquents $(67,0 \%, 201 / 300)$. Les autres bactéries identifiées étaient Staphylococcus aureus (23,7\%, SARM de $3 \%)$, Streptococcus pyogenes $(2,7 \%)$ et Enterobacteriaceae $(6 \%)$. Les isolats étaient très sensibles à I'ofloxacine $96,7 \%(290 / 300)$, à l'augmentationin $87,7 \%(263 / 300)$ et à la ceftriaxone $87,3 \%(262 / 300)$.

Conclusion: Cette étude démontre un taux élevé de contamination des mains des travailleurs de la santé par des bactéries potentiellement pathogènes, dont certaines étaient multirésistantes. Des efforts concertés devraient être faits pour mettre en œuvre des programmes visant à améliorer les pratiques d'hygiène des mains dans les établissements de soins de santé tertiaires.
\end{abstract}

Mots-clés: hygiène des mains, bactérienne, pathogène, personnel de santé, infection associée aux soins de santé

\section{Introduction:}

Healthcare associated infections (HAIs) are a major public health challenge with regards to patients' safety. Approximately $20 \%$ of patients on hospital admission contract HAIs in developing countries (1) resulting in prolonged hospital stay, increased healthcare cost, development of antimicrobial resistance, and increased morbidity and mortality $(2,3,4)$. In the United States of America, an estimated 2 million hospitalized patients are affected by HAIs yearly resulting in mortality of 100,000 patients (1).

The major source for transmission of HAIs is the contaminated hands of healthcare workers (HCWs) $(5,6)$. The objectives of this study are to profile the bacterial pathogens contaminating hands of HCWs during routine patient care, and determine their antimicrobial susceptibility pattern.

\section{Material and methods:}

\section{Study setting}

This study was conducted from May to July, 2019, at the Barau Dikko Teaching Hospital
(BDTH), Kaduna, a tertiary healthcare facility and also a large referral institution providing primary and tertiary medical care for residents in the State and environs. The hospital has several units in which member of staff interact and carry out routine daily patients' care. Ethical permission was obtained from the Hospital Research and Ethics committee and informed consent obtained from all study participants.

\section{Subjects, sampling and bacterial identification}

Three hundred healthcare workers were consecutively selected from five major cadres of staff of the hospital (doctors, nurses, laboratory personnel, attendants, and support staff) and medical students, in equal numbers. The five fingertips of the dominant hand of each subject were imprinted on MacConkey, Mannitol salt and Blood agar plates, which were incubated at $37^{\circ} \mathrm{C}$ for 16-18 hours. Bacteria identification on culture plates was done by Gram staining, conventional biochemicals (catalase, coagulase, triple sugar iron agar, indole, urease citrate, and the Microgen identification kit (Oxoid Ltd, UK). The slide agglutination test with Staphytech (Oxoid Ltd, UK) was used in addition to the con- 
ventional biochemical tests for further identification of the staphylococci.

\section{Antibiotic susceptibility testing}

Antibiotic susceptibility of the isolates was determined by the modified Kirby Bauer disk diffusion method (8) against eight selected antibiotics; ofloxacin 5 $\mathrm{g}$, amoxicillin/clavulanate (augmentin) $30 \mu \mathrm{g}$, gentamicin $10 \mu \mathrm{g}$, cefuroxime $30 \mu \mathrm{g}$, cefotaxime $30 \mu \mathrm{g}$, ceftriaxone $30 \mu \mathrm{g}$, erythromycin $15 \mu \mathrm{g}$, and ampicillin $10 \mu \mathrm{g}$. Cefoxitin $30 \mu \mathrm{g}$ was used as surrogate for the detection of methicillin resistance in Staphylococcus aureus.

A colony of the test organism was picked with sterile wire loop and immersed in peptone water. The turbidity of the suspension was standardized against 0.5 MacFarland standards. The suspension of the organism was streaked with a sterile swab stick on an entire plate of Mueller Hinton agar and the antibiotic disks were placed on the plate using sterile forceps. The susceptibility culture plates were incubated at $37^{\circ} \mathrm{C}$ aerobically for $16-18$ hours while the culture plates for oxacillin resistance testing was incubated for 24 hours. Susceptibility or resistance was determined by measuring the zones of inhibition with a calibrated ruler and interpreted according to the guidelines of the Clinical and Laboratory Standards Institute (9).

\section{Data analysis}

The Statistical Package for the Social Sciences (SPSS) software version 20.0 was used for data analysis.

\section{Results:}

There were 300 study participants with 50 from each of the five cadres of HCWs (doctors, nurses, laboratory personnel, attendants, and support staff mainly administrative officers) and medical students.

\section{Bacteria cultured from hands of participants}

Bacteria were cultured from the hands of all the study participants $(100 \%)$. The most common bacterial isolates were CONS $67 \%$ $(n=201)$, Staphylococcus aureus $23.7 \%(n=71)$, Escherichia coli $4.3 \% \quad(n=13)$, Streptococcus pyogenes $2.7 \%(n=8)$, Klebsiella pneumoniae $1 \%(\mathrm{n}=3)$, Proteus mirabilis $0.7 \%(\mathrm{n}=2)$ and Salmonella typhi $0.7 \%(n=2)$ (Table 1$)$. CONS was most frequently isolated from hands of the support staff with frequency of $20.8 \%(42 / 201)$ and the nurses $19.9 \%(40 / 201)$ while it was least frequently isolated from hands of doctors
$13.4 \%(27 / 201)$ and laboratory personnel $10.5 \%$ (21/201).

Conversely, S. aureus was most frequently isolated from hands of laboratory personnel 33.8\% (24/71) and medical doctors $32.4 \%(23 / 71)$, and least frequently isolated from hands of nurses $7 \%(5 / 71)$ and medical students $7 \%$ (5/71). The Gram-negative bacteria were most frequently isolated from hands of medical students $40 \%(8 / 20)$ and nurses 25\% (5/20) (Table 1).

\section{Susceptibility of the bacterial isolates}

Most of the bacteria (96.7\%) cultured from the hands of the study participants were sensitive to ofloxacin. Sensitivity to other antibiotics were; cefotaxime $(76.7 \%)$, ceftriaxone $(87.3 \%)$, augmentin $(87.7 \%)$, gentamicin $(80.3 \%)$ and erythromycin (62.3\%) (Fig 1 ). Nine of the $71(12.7 \%)$ S. aureus isolates were methicillin resistant.

\section{Discussion:}

The growing awareness of multidrug resistance and the development of 'super bugs' has led to an increasing introspection on the practices in health care facilities which promote the transmission of microorganisms and the role of HCWs in the chain of transmission. Hand hygiene has been identified as a major strategy in reducing the transmission and prevalence of HAIs (10). This study highlights bacterial colonization of the hands of a wide range of HCWs who are constantly caring for patients. These organisms may constitute an infection risk to HCWs and to those seeking care in this healthcare facility.

Our study demonstrates a high rate of hand contamination with CONS and $S$. aureus among the study participants which is consistent with findings of other studies that showed these organisms to be resident and sometimes transient flora (11). Although these organisms have been shown to be non-pathogenic, they have the potential to cause life threatening nosocomial infections in susceptible hosts $(10,12)$.

The least frequently isolated bacteria were $K$. pneumoniae, $P$. mirabilis and $S$. typhi in this study. These Gram-negative bacteria are members of the family Enterobacteriaceae that have the propensity to acquire plasmids which carry genes for drug resistance, and make HAIs caused by these organisms difficult to treat $(13,14)$. They have also been linked with HAIs 
Table 1: Frequency distribution of bacterial isolates on the hands of healthcare workers

\begin{tabular}{|c|c|c|c|c|c|c|c|}
\hline \multirow{2}{*}{$\begin{array}{l}\text { Organism/ Cadre } \\
\text { of HCW }\end{array}$} & Attendant & Doctor & Laboratorian & Nurse & Others & Student & Total \\
\hline & $\mathrm{n}(\%)$ & $\mathrm{n}(\%)$ & n (\%) & $\mathrm{n}(\%)$ & $\mathrm{n}(\%)$ & $\mathrm{n}(\%)$ & $\mathrm{n}(\%)$ \\
\hline CONS & $35(70)$ & $27(54)$ & $21(42)$ & $40(80)$ & $41(82)$ & $37(74)$ & $201(67)$ \\
\hline S. aureus & $7(14)$ & $23(46)$ & $24(48)$ & $5(10)$ & $7(14)$ & $5(10)$ & $71(23.7)$ \\
\hline *MRSA & $5(10)$ & 0 & $2(4)$ & $2(4)$ & 0 & 0 & $9(3)$ \\
\hline S. pyogenes & $5(10)$ & 0 & $2(4)$ & 0 & $1(2)$ & 0 & $8(2.7)$ \\
\hline E. coli & 0 & 0 & $2(4)$ & $3(6)$ & $1(2)$ & $7(14)$ & $13(4.3)$ \\
\hline K. pneumoniae & $1(2)$ & 0 & 0 & $1(2)$ & 0 & $1(2)$ & $3(1)$ \\
\hline P. mirabilis & $1(2)$ & 0 & 0 & $1(2)$ & 0 & 0 & $2(0.7)$ \\
\hline S. typhi & $1(2)$ & 0 & $1(2)$ & 0 & 0 & 0 & $2(0.7)$ \\
\hline Total & $50(100)$ & $50(100)$ & $50(100)$ & $50(100)$ & $50(100)$ & $50(100)$ & $300(100)$ \\
\hline
\end{tabular}

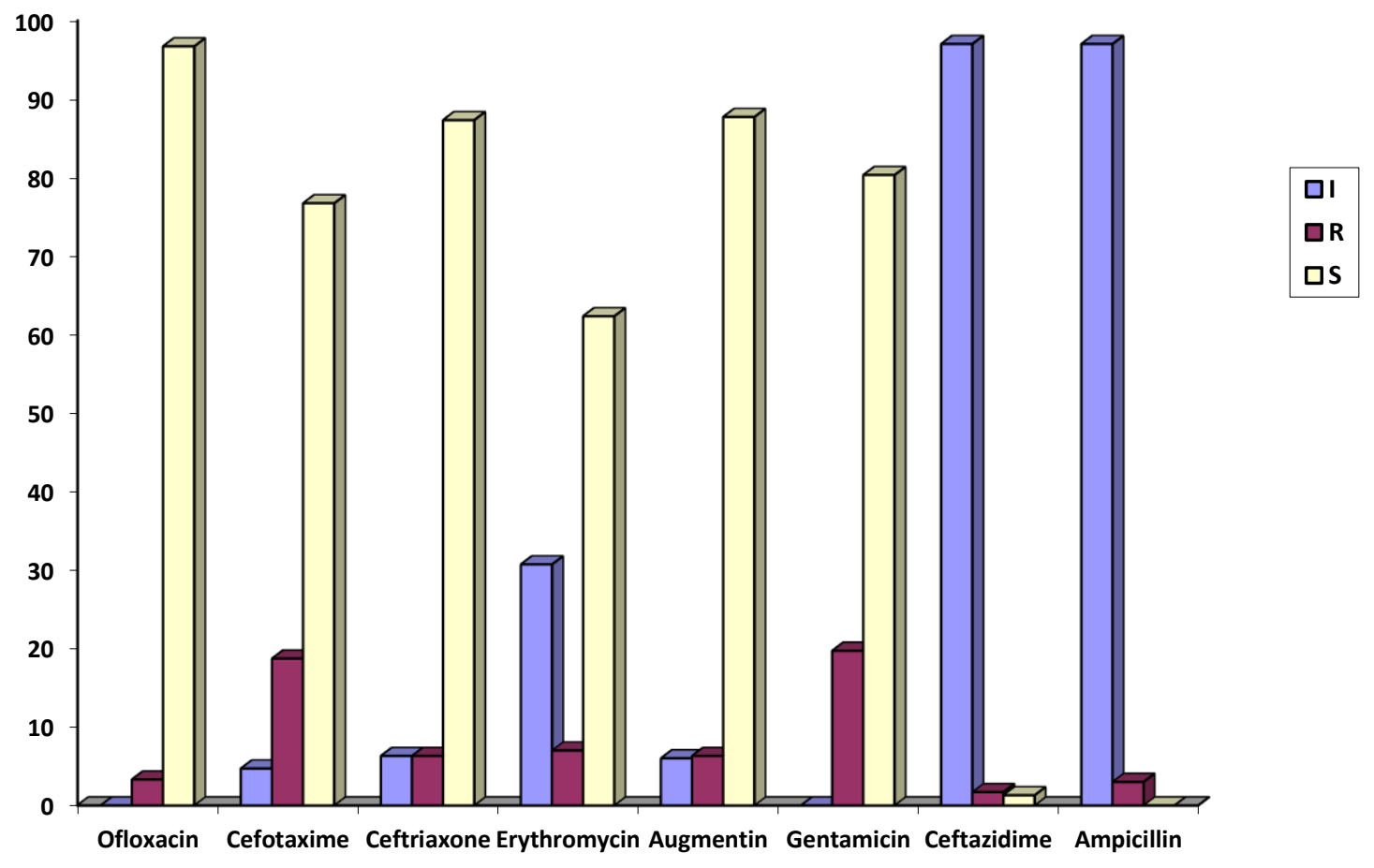

Fig 1: Histogram showing antimicrobial susceptibility pattern of isolated bacteria

following the use of ventilator or urethral catheterization, and after faeco-oral transmission. Sixty-two $(87.4 \%)$ out of the 71 isolates were methicillin sensitive $S$. aureus (MSSA) while 9
$(12.7 \%)$ were methicillin resistant $S$. aureus (MRSA). This MRSA rate is lower than the rates reported by Fadeyi et al., (15) and Abdullahi and Iregbu (16). 
Some cadres of staff in the study were more frequently colonized with one bacterial than the other for example nurses and support staff were most frequently colonized with CONS while doctors and laboratory personnel were least frequently colonized. Conversely, doctors and laboratory personnel were most frequently colonized with $S$. aureus. Also, medical students and nurses were most frequently colonized with Gram negative bacteria while doctors were least frequently colonized. These findings contrast those of previous studies $(17,18)$.

Poor hand hygiene performance has been documented amongst HCWs in Kano, a city in northwest Nigeria (19). Therefore, our findings may be indicative of low compliance across many health institutions across the country and suggests instituting and implementing policies which govern and guide hand hygiene practices and continuous training across all cadres of HCWs including students. The high frequency of E. coli contaminating hands of medical students observed in our study is similar to that of Watutantrige et al., (10). This may be due to poor toilet and hand hygiene practices by the students as postulated by the study.

The high frequency of isolation of $S$. aureus among laboratory personnel is similar to the findings in Guangzhou, China, which showed that medical laboratory staff especially those in the microbiological laboratories had significant exposure to $S$. aureus with increased risk of colonization and infection from contact with patient samples. S. aureus contamination of HCWs has previously been linked to the contamination of white coats which act as potential reservoirs of infection and re-infection (20). This may also explain why medical doctors had the highest percentage of carriage of $S$. aureus in this study.

The isolates showed highest sensitivity to ofloxacin, augmentin and ceftriaxone (all bacteria) and least sensitivity to erythromycin (S. aureus, CONS), ampicillin and ceftazidime (enteric bacteria). Similar patterns of susceptibility were reported for isolates in the study by Abdullahi and Iregbu (16) with detection of significant resistance of $S$. aureus to penicillin, erythromycin and clindamycin but sensitivity to vancomycin, cefazolin and imipenem.

\section{Conclusion:}

This study demonstrates a high rate of contamination of hands of HCWs by potentially pathogenic microorganisms, some of which are multidrug resistant. Improvement of hand hygiene practices is necessary to minimize the risk of cross contamination and spread of infectious pathogens in healthcare facilities

\section{References:}

1. World Health Organization. WHO guidelines on hand hygiene in health care: first global patient safety challenge clean care is safer care. Geneva: WHO Health Organization, Patient Safety; 2009

2. Bouwe, R M., Labuschagne, S., Spamer, S., Vermaak, C., Zietsman L. M, Steyn, D., and Joubert, G. Knowledge of final-year medical students at the University of the Free State of hand hygiene as a basic infection control measure, South African Family Practice 2018; 60 (3): 74-78

3. $\mathrm{CDC} / \mathrm{NHSN}$. Surveillance definition of health careassociated infection and criteria for specific types of infections in the acute care setting. Am J Infect Control. 2008; 36: 309-332

4. Geberemariyam, B. S., Donka, G. M., and Wordofa, B. Assessment of knowledge and practices of healthcare workers towards infection prevention and associated factors in healthcare facilities of West Arsi District, Southeast Ethiopia: a facility-based cross-sectional study. Arch Publ Hlth. 2018; 76: 69

5. Singh, S., and Singh, A. K. Prevalence of bacteria contaminating hands of healthcare workers during routine healthcare. A hospital-based study. J Acad Clin Microbiol 2016; 18: 60-62

6. Shobowale, E. O., Onyedibe, K. I., Adegunle, K. B., and Elikwu, C. J. An Observational and Trend Analysis Study of Hand Hygiene Practices of Healthcare Workers at A Private Nigerian Tertiary Hospital. Ann Med Health Sci Res. 2017; 7: 84-89

7. Cheesbrough, M. District Laboratory practice in tropical countries. Cambridge University Press, $3^{\text {rd }}$ edition. 2009

8. Bauer, A. W., Kirby, W. M., Sherris, J. K., and Turck, M. Antibiotic Susceptibility testing by a standard single disc method. Am J Clin Pathol. 1966; 45: 493-496

9. Clinical and Laboratory Standards Institute (CLSI). Performance standards for antimicrobial susceptibility testing; Twenty-second Informational Supplement; 32 (3): M100-S2, 2012.

10. Watutantrige R D. Premalatha, P., Lum W. S., and Xiaofen, E. C. "A Study on Hand Contamination and Hand Washing Practices among Medical Students" ISRN Public Health. 2012: Article ID 251483. https://doi.org/10.5402/2012/251483.

11. Yusuf, J. B., Okwong, O. K., Mohammed, A., Saidu, K., Babayo, A., and Barma, M. M. Bacterial Contamination of Intensive Care Units at a Tertiary Hospital in Bauchi, Northeastern Nigeria. Am J Intern Med. 2017; 5 (3): 46-51

12. Günter, K. and Axel, K. Epidemiologic Background of Hand Hygiene and Evaluation of the Most Important Agents for Scrubs and Rubs. Clin Microbiol Rev. 2004; 17 (4): 863-893. doi:10.1128 /CMR.17.4.863-893.2004

13. Paczosa, M. K., and Mecsas, J. Klebsiella pneumoniae: going on the offense with a strong defense. Microbiol Mol Biol Rev. 2016; 80: 629-661. doi:10.1128/MMBR.00078-15.

14. Bobo, L. D., and Dubberke, E. R. Recognition and prevention of hospital-associated enteric infections in the intensive care unit. Crit Care Med. 2010; 38 (8 Suppl): S324 - S334. doi:10.1097/CMM.0b013e 3181e69f05

15. Fadeyi, A., Adeboye, M. A. N., Fowotade, A., et al. Methicillin resistant Staphylococcus aureus carriage amongst healthcare workers of the critical care 
units in a Nigerian hospital. Am J Infect Dis. 2010; 6 (1): 18-23.

16. Abdullahi, N., and Iregbu, K. C. MethicillinResistant Staphylococcus aureus in a Central Nigeria Tertiary Hospital. Ann Trop Pathol. 2018; 9: 6-10.

17. Rincy S., Mathew, R., Ambica, P., and Shantala, G. B. Study of Bacteriological Profile on Hands of Health Care Workers in ICU Setup in a Tertiary Care Hospital. Int J Curr Microbiol Appl Sci. 2017; 6 (12): 2698-2702.

https://doi.org/10.20546/ijcmas.2017.612.312

18. Pittet, D. Compliance with hand disinfection and its impact on hospital-acquired infections. J Hosp Infect.
2001; 48 (Suppl A): S40 - S46. doi:1016/s01956701(01)90012-x

19. Gwarzo, G. D. Hand hygiene practice among healthcare workers in a public hospital in North -Western Nigeria. Niger J Basic Clin Sci. 2018; 15: 109-113.

20. Xie, X., Dai, X., Ni, L., et al. Molecular epidemiology and virulence characteristics of Staphylococcus aureus nasal colonization in medical laboratory staff: comparison between microbiological and nonmicrobiological laboratories. BMC Infect Dis. 2018: 18: 122. https://doi.org/10.1186/s12879018-3024-x 